Pak. j. sci. ind. res. Ser. B: biol. sci. 2018 61B(2) 68-71

\title{
Response of Wheat to Gypsum Application at Farmers Fields in Rainfed Pothwar
}

\author{
Adnan Umair ${ }^{a *}$, Muhammad Nadeem Iqbal' ${ }^{\mathrm{b}}$ Kashif Bashir ${ }^{\mathrm{a}}$, Khadim Hussain ${ }^{\mathrm{c}}$, Waqas Naseem ${ }^{\mathrm{d}}$, \\ Muhammad Rafique Sajjad ${ }^{\mathrm{c}}$, Tariq Mehmood ${ }^{\mathrm{d}}$ and Ghulam Qadir \\ ${ }^{a}$ Soil and Water Conservation Research Station, Sohawa, Pakistan \\ ${ }^{b}$ Soil Fertility Research Institute, Lahore, Pakistan \\ 'Soil Testing Laboratory, Jhelum, Pakistan \\ ${ }^{\mathrm{d} S}$ Soil and Water Conservation Research Institute, Chakwal, Pakistan \\ e'Soil Salinity Research Institute, Pindi Bhatian, Pakistan
}

(received February 17, 2016; revised February 20, 2017; accepted February 21, 2017)

\begin{abstract}
In present study, possibility of use and dose of gypsum was explored in various agro-ecologies of Pothwar region, Pakistan. Experiments were conducted at farmers' fields for three years i.e., 2002-2003 to 2004-2005 at three different districts viz. Chakwal, Attock, Jhelum and Rawalpindi. After first rainfall of monsoon in the end of June, deep ploughing was done in the field with mouldboard plough. After that, gypsum was applied @ 1.25, 2.5, 5.0 and 7.5 t/ha to experimental plots. Application of gypsum resulted in increase in grain yield of wheat during three years. Application of gypsum increased grain yield in all the districts. There was 11.9 to 34 percent increase in wheat yield with application of $2.5 \mathrm{t} / \mathrm{ha}$ of gypsum. At experimental plots, where grain yields were less than $3.1 \mathrm{t} / \mathrm{ha}$ after application of $2.5 \mathrm{t} / \mathrm{ha}$ of gypsum, increasing gypsum application beyond $2.5 \mathrm{t} / \mathrm{ha}$ increased the yield further. However, at sites, where grain yields were more than $3.4 \mathrm{t} /$ ha with application of gypsum @ $2.5 \mathrm{t} / \mathrm{ha}$, further increase in gypsum dose beyond $2.5 \mathrm{t} / \mathrm{ha}$ decreased the yields. On the basis of these experiments, $2.5 \mathrm{t} / \mathrm{ha}$ was found the appropriate dose of gypsum for rainfed wheat.
\end{abstract}

Keywords: gypsum, wheat, rainfed, rainfall, Pothwar

\section{Introduction}

Wheat is grown over an area of about 9.2 million hectares in Pakistan (GOP, 2015-16) out of which 6.9 million hectares is situated in Punjab province and ten percent of this area is rainfed. Most of rainfed area of wheat is situated in Pothwar plateau, Pakistan. In Pothwar (latitude $32^{\circ} 10^{\prime}$ to $34^{\circ} 9^{\prime} \mathrm{N}$; longitude $71^{\circ} 10^{\prime}$ to $73^{\circ}$ $55^{\prime} \mathrm{E}$ ), average annual rainfall ranges from 400 to 900 $\mathrm{mm}$ on spatial scale, with northern parts getting comparatively more rainfall.

Behaviour of rainfall is highly variable, but generally two third of it occurs in the form of high intensity rain storms during monsoon season from July to September. Wheat crop is sown in the end of October, therefore, the success of this crop is directly related to the success in conservation of rainfall during monsoon months. Average grain yield of rainfed wheat in Pakistan is lower due to erratic and lower rainfall. Deep ploughing at the start of monsoon is a common practice amongst the farmers to receive and store rainfall in the field. Pre-monsoon application of gypsum also improves the wheat yield through conservation of rainfall water.

*Author for correspondence; E-mail: adnanumair@gmail.com
Application of gypsum before start of monsoon has already been proved to improve wheat yield through improvement of soil moisture in Chakwal (Pothwar) (Rashid et al., 2008). In his study, soil moisture was improved at every depth with application of gypsum. This improvement of soil moisture could be the result of increased infiltration rate and elimination of surface sealing as reported by Yu et al. (2003) in his study. He studied the effect of polyacrylamide (10 and $20 \mathrm{~kg} / \mathrm{ha}$ and gypsum ( 2 and $4 \mathrm{t} / \mathrm{ha}$ ). He observed that spreading gypsum at the soil surface doubled the final water infiltration rate compared to that of control. In another study reported by Thomas et al. (1995) he observed an increase in yields (15 percent) both in wheat and sorghum with application of gypsum. Similarly, Toma et al. (1999) observed 50 percent increase in corn (Zia mays L.) and alfalfa (Medicago sativa L.) and attributed it to higher exchangeable $\mathrm{Ca}$ and $\mathrm{S}$. In a previous study, reported by Rashid et al. (2008), effect of gypsum application was investigated on-farm at Chakwal. Therefore, present study was carried out to ascertain the response of gypsum application on the yield of succeeding wheat crop at farmer fields in various rainfall zones of Pothwar. 


\section{Materials and Methods}

Experiments were conducted from 2002-03 to 2004-05 at farmers, fields at three different locations (based on low, medium and high rainfall) viz. Fatehjang, district Attock, district Chakwal, and Sohawa, district Jhelum in Pothwar. Deep ploughing of soil was done with mould board plough after first rainfall of monsoon in first week of July and gypsum was applied. During first year, two levels of gypsum were applied @ 2.5 and 5.0 $\mathrm{t} / \mathrm{ha}$ and mixed with shallow cultivation. However, during next two years, four levels of gypsum were applied @ 1.25, 2.5, 5.0 and 7.5 t/ha. Farmer practice of no gypsum was also included as a treatment. All fields were cultivated during monsoon when needed to control weeds according to the general practice of the farmers. Inqulab 91 variety of wheat was sown in end of October. Sowing was done with automatic Rabi drill using $125 \mathrm{~kg}$ /ha of seed rate. Fertilizer was applied @ $120-80-60 \mathrm{~kg} / \mathrm{ha}$ of $\mathrm{N}-\mathrm{P}_{2} \mathrm{O}_{5}-\mathrm{K}_{2} \mathrm{O}$. Harvesting of wheat was carried out in mid of April and yield data were recorded. Whole plot was harvested with mini-reaper for taking the yield data. Experiment was conducted at new site each year with plot size of $12 \mathrm{~m} \times 12 \mathrm{~m}$ in randomized complete block design with four repeats.

Soil analysis. Soil samples were collected from 0-15 and $15-30 \mathrm{~cm}$ depths from all the fields and brought to the laboratory. Electrical conductivity (ECe) and $\mathrm{pHs}$ of soil were determined from saturated soil paste (Richard, 1954). These samples were analyzed for organic matter (Walkley and Black, 1934), available P
(Watanabe and Olson, 1965), Extractable K (Rhoades, 1982) and texture (Bouyoucus method). Statistical analysis was carried out using "MSTATC" program by applying the methods of Steel and Torrie (1980). Duncan's multiple range test was employed for calculating least significance difference between means (Duncan, 1955). Meteorological data were recorded at meteorological observatories located at research station near experimental sites.

\section{Results and Discussion}

Soil status. Experimental fields were found free of any salinity/sodicity problem electrical conductivity (ECe) less than $4.0 \mathrm{dS} / \mathrm{m}$ and having $\mathrm{pHs}$ in the range of 7.7 to 7.8 (Table 1). Sites were poor in organic matter which ranged between 0.54 and 0.62 percent. Similarly, available phosphorus was also poor ranging from 5.3 to $7.9 \mathrm{mg} / \mathrm{kg}$. Extractable potash was less than 180 $\mathrm{mg} / \mathrm{kg}$ at all experimental sites. Dominant soil texture was sandy loam.

Rainfall data. Rainfall data of experimental sites are presented in Fig. 1 whereas seasonal rainfall figures have been presented in Table 2 which show the distribution of rainfall.

Grain yield. During 2002-03, four experiments were conducted at farmers' fields in each district i.e. Chakwal, Attock and Jhelum/Rawalpindi. Data are presented in Fig. 2. Grain yield of wheat was increased by 28.3, 20.7 and 11.9 percent over control with application of 2.5 t/ha of gypsum districts of Chakwal, Attock and Jhelum/Rawalpindi respectively. The yield was further

Table 1. Pre-sowing soil status of three sites

\begin{tabular}{|c|c|c|c|c|c|c|c|c|c|}
\hline \multirow[t]{2}{*}{ Year } & \multicolumn{3}{|c|}{ Fatehjang } & \multicolumn{3}{|c|}{ Sohawa } & \multicolumn{3}{|c|}{ Chakwal } \\
\hline & OM \% & $\begin{array}{l}\text { Av P } \\
(\mathrm{mg} / \mathrm{kg})\end{array}$ & $\begin{array}{l}\text { Ex K } \\
(\mathrm{mg} / \mathrm{kg})\end{array}$ & $\begin{array}{l}\mathrm{OM} \\
\%\end{array}$ & $\begin{array}{l}\text { Av P } \\
(\mathrm{mg} / \mathrm{kg})\end{array}$ & $\begin{array}{l}\mathrm{Ex} \mathrm{K} \\
(\mathrm{mg} / \mathrm{kg})\end{array}$ & $\begin{array}{l}\mathrm{OM} \\
\%\end{array}$ & $\begin{array}{l}\text { Av P } \\
(\mathrm{mg} / \mathrm{kg})\end{array}$ & $\begin{array}{l}\text { Ex K } \\
(\mathrm{mg} / \mathrm{kg})\end{array}$ \\
\hline 2002-03 & 0.54 & 7.90 & 104 & 0.51 & 6.50 & 109 & 0.46 & 4.70 & 119 \\
\hline 2003-04 & & 5.3 & 112 & 0.43 & 4.02 & 130 & 0.54 & 6.68 & 102 \\
\hline 2004-05 & 0.62 & 5.82 & 122 & 0.47 & 4.38 & 141 & 0.59 & 7.28 & 111 \\
\hline
\end{tabular}

Table 2. Seasonal rainfall at experimental sites

\begin{tabular}{|c|c|c|c|c|c|c|}
\hline \multirow[b]{2}{*}{ Site } & \multicolumn{3}{|c|}{ June to September } & \multicolumn{3}{|c|}{ October to April } \\
\hline & $2002-03$ & 2003-04 & 2004-05 & $2002-03$ & 2003-04 & 2004-05 \\
\hline Chakwal & 691 & 365 & 366 & 199 & 156 & 283 \\
\hline Fatehjang & 464 & 458 & 432 & 257 & 180 & 497 \\
\hline Sohawa & 748 & 546 & 528 & 355 & 188 & 575 \\
\hline Mean & 634 & 456 & 442 & 270 & 175 & 452 \\
\hline
\end{tabular}


enhanced with application of higher dose (5.0 t/ha) of gypsum. Total rainfall occurring from October 2002 to March 2003 was 199, 257 and $355 \mathrm{~mm}$ respectively. In Jhelum / Rawalpindi, the best dose was one $\mathrm{t} / \mathrm{ha}$ while in Attock district maximum yield was observed with two $\mathrm{t} / \mathrm{ha}$ of gypsum.

During next year i.e. 2003-04, four, five and eight experiments were conducted at farmers' field in Chakwal, Attock and Jhelum/Rawalpindi districts respectively. It was comparatively a dry year and rabi rainfall during Oct. 2003 to March 2004 was 156, 180 and $188 \mathrm{~mm}$ respectively. During this year, maximum increase was with one ton per acre of gypsum in Jhelum/Rawalpindi and Attock districts i.e. 15, 34 and 22 percent (Fig. 3). Increasing the dose of gypsum above $2.5 \mathrm{t} / \mathrm{ha}$ did not increase the yield further in District Attock and Jhelum/ Rawalpindi. However, in Chakwal higher doses i.e. 5.0 and $7.5 \mathrm{t} / \mathrm{ha}$ also increased the yield over control.

During 2004-05, three and seven experiments were conducted in Chakwal and Jhelum / Rawalpindi districts respectively. In Districts of Jhelum/Rawalpindi, grain yield was increased from 3.65 to $4.78 \mathrm{t} / \mathrm{ha}$ registering $31 \%$ increase with $2.5 \mathrm{t} / \mathrm{ha}$ of gypsum and further increase in dose of gypsum decreased the yield (Fig. 4). In Chakwal, yield was increased from 3.02 to $3.78 \mathrm{t} / \mathrm{ha}$ with $14 \%$ increase in yield with $2.5 \mathrm{t} / \mathrm{ha}$ of gypsum over no gypsum.

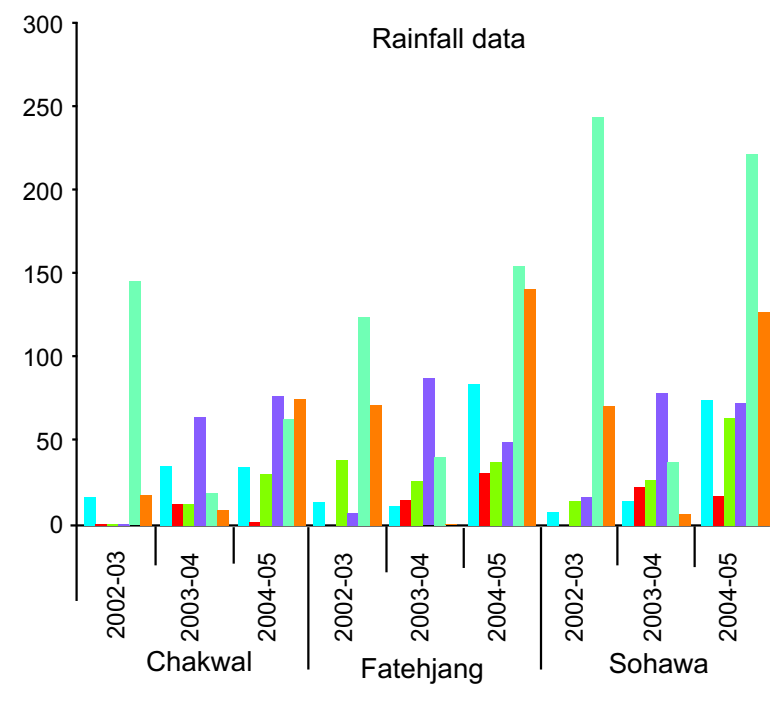

Oct Nov Dec $\square$ Jan Feb Mar

Fig. 1. Rainfall during the experiment at all the sites

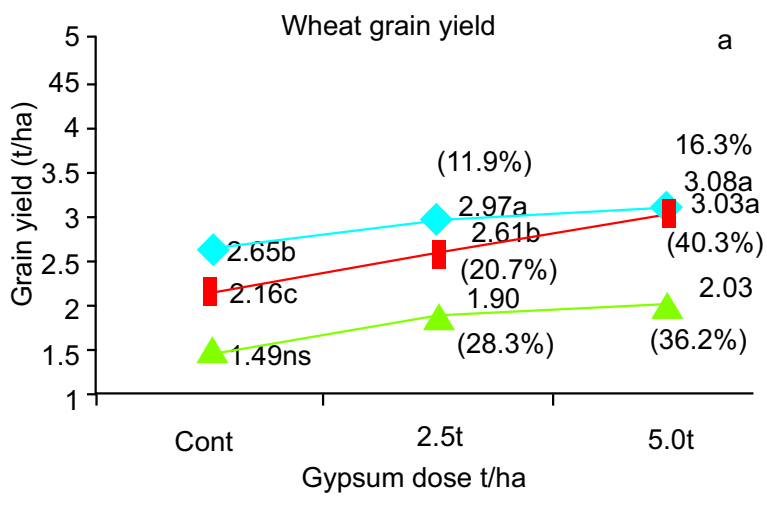

Sohawa 2002-03 - Fatehjang 2002-03 - Chakwal 2002-03

Fig. 2. Grain yield of wheat at farmers' fields (2002-03)



Fatehjang 2003-04 - Sohawa 2003-04 - Chakwal 2003-04

Fig. 3. Grain yield of wheat at farmers' fields (2003-04)

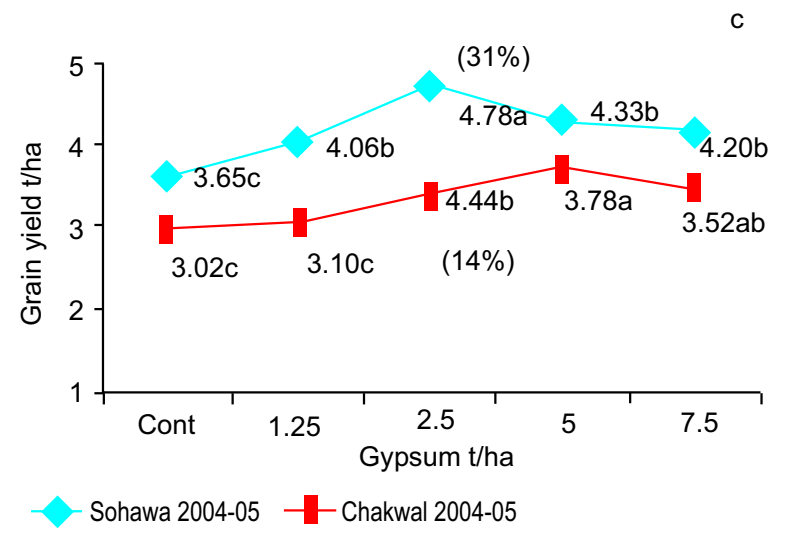

Fig. 4. Grain yield of wheat at farmers' fields (2004-05) 
In 2002-03, grain yields of wheat were low due to less rainfall in the months from Nov 2002 to Jan 2003 (crop establishment stage) at all sites as compared to the same period in 2003-04. In 2004-05, though the same period rainfall (Nov-Jan) and overall rainfalls were higher but rust attack on variety Inqulab-91 decreased the overall yields in Pothwar. Generally, it was observed that when grain yields were comparatively lower, increasing the gypsum dose above $2.5 \mathrm{t} / \mathrm{ha}$ increased the yield. However, when grain yields were comparatively higher (greater than $3.1 \mathrm{t} / \mathrm{ha}$ ), further enhancement in dose of gypsum decreased the yield. On the basis of these findings, $2.5 \mathrm{t} /$ ha may be taken as the safer dose of gypsum for rainfed wheat in all districts of Pothwar region. Similar results were observed by Hamza and Anderson (2004) when they used $2.5 \mathrm{t} /$ ha of gypsum as single dose on two soils i.e. loamy sand and sandy clay loam in Western Australia with problem of compaction. A combination of deep ripping and gypsum treatment increased the soil water infiltration rate by about $90 \%$ on the loamy sand soil but by more than $130 \%$ on the sandy clay loam soil 4 years after the application of the treatments. He noticed that the summer rain stored in the soil prior to seeding was increased almost 3 times in both soils. Moreover, in present study, higher doses of gypsum increased the yields in cases when November to January rainfall was lower.

These results were inconsistence with earlier studies of Rashid et al. (2008) and Farina et al. (2000). Greater benefit of gypsum during years of drought was also observed by Farina et al. (2000) while working on the strategy to ameliorate subsoil acidity. They found that, yield benefits to maize crop due to gypsum were greatest in seasons of severe moisture stress. They also noted that except for the 1988-89 season, during which postanthesis precipitation was particularly good, the benefit imparted by gypsum consistently, exceeded one ton per hectare over the conventional treatment.

\section{Conclusion}

This study revealed that the gypsum application increased grain yield of wheat under rainfed conditions of Pothwar and $2.5 \mathrm{t} / \mathrm{ha}$ of gypsum was the appropriate dose in rainfed Pothwar. However, the solubility of gypsum is usually low. Therefore, the beneficial impact of gypsum is available for more than one year.

\section{References}

Duncan, D.B. 1955. Multiple range and multiple FTest. Biometerics, 11: 1-42.

GOP, 2016. Pakistan Economic Survey 2015-16, Government of Pakistan, Ministry of Finance, Islamabad.

Hamza, M.A., Anderson, W.K. 2004. Responses of soil properties and grain yields to deep ripping and gypsum application in a compacted loamy sand soil contrasted with a sandy clay loam soil in Western Australia. Australian Journal of Agricultural Research, 54: 273-282.

Rashid, M., Iqbal, M. N., Akram, M., Ansar, M., Hussain, R. 2008. Role of gypsum in wheat production in rainfed areas. Soil and Environment, 27: 166-170.

Rhoades, J.D. 1982. Cation exchange capacity. In: Methods of Soil Analysis, Part 2. Chemical and Microbiological Properties. A.L. Page (ed.). American Society of Agronomy, pp, 149-158 Madison, Wisconsin, USA.

Richard, L.A. 1954. Diagnosis and Improvement of Saline and Alkali Soils. USDA Handbook 60.

Steel, R.G.D., Torrie, J.H. 1980. Principles and Procedures of Statistics. Mc Graw Hill Co. Inc. New York, USA.

Thomas, G.A., Gibson, G., Nielsen, R.G.H., Martin, W.D., Radford, B.J. 1995. Effects of tillage, stubble, gypsum, and nitrogen fertilizer on cereal cropping on a red brown earth in southwest Queensland. Australian Journal of Experimental Agriculture, 35: $997-1008$.

Toma, M., Sumner, M.E., Weeks, G., Saigusa, M. 1999. Long-term effects of gypsum on crop yield and subsoil chemical properties, Soil Science Society of America Journal, 63: 891-895.

Walkley, A., Black, C.A. 1934. An examination of Degtjareff methods for determining soil organic matter and a proposed modifications of the chromic acid titration method. Soil Science, 37: 29-38.

Watanabe, F.S., Olsen, S.O. 1965. Method for determination of phosphorus in water and $\mathrm{NaHCO}_{3}$ extracts from soil. Soil Science Society America Proceedings, 29: 677-678.

Yu, J., Lei, T., Shainberg, I., Mamedov, A.I., Levy, G.J. 2003. Infiltration and erosion in soils treated with dry PAM and gypsum. Soil Science Society of America Journal, 67: 630-636. 